\title{
miR-183 regulates biological behavior in papillary thyroid carcinoma by targeting the programmed cell death 4
}

\author{
CHUANKUI WEI $^{1 *}$, HONGMING SONG $^{1^{*}}$, XIAOGUO SUN ${ }^{2}$, DENGFENG LI ${ }^{1}$, \\ JIALU SONG $^{1}$, KAIYAO HUA ${ }^{1}$ and LIN FANG $^{1}$ \\ ${ }^{1}$ Department of General Surgery, Shanghai Tenth People's Hospital, Tongji University School of Medicine, Shanghai 200072; \\ ${ }^{2}$ Department of General Surgery, First People's Hospital of Taian, Taian, Shandong 271000, P.R. China
}

Received January 19, 2015; Accepted April 30, 2015

DOI: $10.3892 /$ or.2015.3971

\begin{abstract}
Numerous studies have demonstrated that microRNAs (miRNAs) play vital roles in papillary thyroid carcinoma (PTC). The aim of the present study was to examine the expression levels of miR-183 in PTC and investigate whether its potential roles involved targeting the programmed cell death 4 (PDCD4). Reverse transcription-quantitative polymerase chain reaction (RT-qPCR) was used to examine the expression levels of miR-183 in 38 PTC specimens and 4 PTC cell lines. MTT, colony formation, wound-healing and Transwell invasion assays, and flow cytometry were conducted to explore the potential functions of miR-183 in human TPC1 papillary thyroid carcinoma cells. The dual-luciferase reporter assay was performed to validate whether PDCD4 was a direct target of miR-183. The effects of modulating miR-183 on endogenous levels of PDCD4 were subsequently confirmed via RT-qPCR and western blotting. Functional assays were used to indicate the roles of endogenous PDCD4 in TPC1. The results showed the miR-183 expression levels were significantly upregulated in PTC specimens and cell lines $(\mathrm{P}<0.05)$. Overexpression of miR-183 in TPC1 promoted cell proliferation, migration, invasion and decreased apoptosis. The dual-luciferase reporter assay confirmed that PDCD4 was a direct target of miR-183. RT-qPCR and western blotting showed that miR-183 negatively regulated PDCD4 protein expression but had no impact on mRNA expression of PDCD4. Knockdown of PDCD4 expression in TPC1 cells significantly enhanced cell proliferation, migration, invasion and inhibited apoptosis. The results of the present study suggested that miR-183 acts as a papillary thyroid carcinoma oncogene through the negative regulation of PDCD4 protein expression at the post-transcriptional levels. Therefore, targeting miR-183
\end{abstract}

Correspondence to: Professor Lin Fang, Department of General Surgery, Shanghai Tenth People's Hospital, Tongji University School of Medicine, 301 Middle Yanchang Road, Shanghai 200072, P.R. China

E-mail: syjrkfanglin@126.com

*Contributed equally

Key words: papillary thyroid carcinoma, miR-183, PDCD4 provides a novel strategy for the diagnosis and treatment of patients with PTC.

\section{Introduction}

Thyroid cancer is the most common endocrine malignancy and its incidence is on the increase $(1,2)$. Four main types of thyroid cancer have been identified: papillary, follicular, medullary and anaplastic thyroid cancer. Papillary thyroid carcinoma (PTC) is the most frequently occurring type of thyroid malignancy accounting for $\sim 80-90 \%$ of cases (3). This cancer type is the most rapidly increasing cancer among women and the second most among men (4), and poses a serious threat to human health and life.

Although most PTC can be managed successfully with a combination of radioiodine and levothyroxine treatment after complete thyroidectomy, tumors with more aggressive phenotype are associated with morbidity and mortality (5). Thus, understanding the molecular mechanism of PTC is important for the development of more effective therapeutic strategies.

MicroRNAs (miRNAs) are a class of small non-coding RNAs with an approximate length of 21-23 nt, which are highly conserved. miRNAs regulate the expression of various genes at the post-transcriptional level by binding to the 3'-untranslated region (3'-UTR) of their target mRNAs (6-8). When the miRNA is perfectly complementary to its target, it can specifically cleave the target mRNA. However, when partially complementary to its target, the miRNA only represses mRNA translation $(9,10)$. Although miRNAs constitute only $3 \%$ of the human genome, it is reported that $\sim 90 \%$ of genes serve as miRNA targets. miRNAs are involved in biological processes such as cell proliferation and differentiation, metabolism, invasion, metastasis and apoptosis, all of which are associated with tumorigenesis (11-14). Previous findings showed that $>50 \%$ of annotated human miRNAs are located in the fragile sites of the genome connected with cancer (15). It has been widely shown that miRNAs are significantly differentiated between tumor and normal tissues, including thyroid cancer (16-18), and may act as oncogenes or tumor suppressor genes $(19,20)$. miR-221, miR-222 and miR-181b have been found to be upregulated in PTC compared with normal thyroid tissue (21-23). Using miRNA microarray chip, it was found that miR-183 was overexpressed in PTC compared with normal thyroid tissues. 
However, the roles of miR-183 in PTC and the mechanism of gene regulation remain to be determined.

Programmed cell death 4 (PDCD4), a tumor-suppressor gene, has been reported to be involved in tumor progression, apoptotic machinery, cell transformation and invasion. PDCD4 protein is downregulated or lost in many human types of cancer and cancer cell lines (24-31), including PTC $(32,33)$. Using programs available online, we determined that miR-183 potentially regulates the PDCD4 gene. Previous results indicated that miR-183 inhibited the apoptosis of TGF- $\beta 1$-induced human hepatocellular carcinoma (HCC) cells by repressing PDCD4 expression (34). Additionally, miR-183 promotes proliferation and invasion in oesophageal squamous cell carcinoma by targeting PDCD4 (35). Nevertheless, whether miR-183 negatively regulates PDCD4 expression in papillary thyroid cancer remains to be determined.

In the present study, we investigated whether miR-183 was upregulated in PTC clinical samples and cell lines. The ectopic expression of miR-183 induced significant changes of cell proliferation, migration, invasion and apoptosis by directly targeting PDCD4. The present study findings identified a novel strategy for the early diagnosis and treatment of PTC.

\section{Materials and methods}

Specimens. In the present study, 38 pairs of papillary thyroid cancer and adjacent normal thyroid specimens were obtained from the Department of Breast and Thyroid Surgery of the Shanghai Tenth People's Hospital and approved by the Institutional Ethics Committee of the Shanghai Tenth People's Hospital (no. SHSY-IEC-pap-15-1). Each patient provided written informed consent. The samples were immediately snap-frozen in liquid nitrogen. The specimens were pathologically confirmed as papillary thyroid carcinoma. No patients had received any chemotherapy or radiotherapy prior to surgery.

Cell lines and transfection. The human TPC-1, BCPAP, K1 and NPA PTC cell lines, human normal thyroid cell line (Nthy-ori 3-1) and HEK293T cells were purchased from the Chinese Academy of Sciences (Shanghai, China). TPC-1, K1, NPA and Nthy-ori 3-1 cells were cultured in RPMI-1640 supplemented with $10 \%$ fetal bovine serum (FBS) (both from Gibco, Carlsbad, CA, USA), penicillin (100 U/ml) and streptomycin $(100 \mu \mathrm{g} / \mathrm{ml})$ (Enpromise, China). BCPAP and HEK293T cells were cultured in Dulbecco's modified Eagle's medium (DMEM) (Gibco) supplemented with 10\% FBS, $1 \%$ penicillin and $1 \%$ streptomycin. The cells were incubated at $37^{\circ} \mathrm{C}$ with $5 \% \mathrm{CO}_{2}$ in saturated humidity.

miR-183 mimics, inhibitors, PDCD4 siRNA or their negative control (NC) were purchased from GenePharma (Shanghai, China). The TPC-1 cells were cultured to $30-40 \%$ confluence in 6-well plates (BD Biosciences, Franklin Lakes, NJ, USA) and were transfected with miR-183 mimics, miR-183 inhibitors, PDCD4 siRNA or their NC at working concentrations using Lipofectamine 2000 (Invitrogen, Carlsbad, CA, USA), according to the manufacturer's instructions. miRNA NC and siRNA NC were used as NCs.

miRNA isolation and reverse-transcription-quantitative polymerase chain reaction ( $R T-q P C R)$. miRNAs were harvested from tissues and cells using a miRcute miRNA Isolation kit (Tiangen, Beijing, China), according to the manufacturer's instructions. miR-183 expression levels were detected using one-step RT-qPCR (EzOmics SYBR qPCR kit). The miR-183 and U6 primer, and EzOmics SYBR qPCR kit were purchased from Biomics Biotechnologies Inc. (Jiangsu, China). U6 was used as an internal control. The miR-183 stem-loop RT primer usedwas: 5'-GCGAGCACAGAATTAATACGACTCACTATA GGT-3'; miR-183 5'-TATGGCACTGGTAGAATTCACT-3' (sense), and 5'-GCGAGCACAGAATTAATACGAC-3' (antisense); while that of U6 stem-loop RT primer was: 5'-GTC GTATCCAGTGCAGGGTCCGAGGTGCACTGGATACGA CAAAATATGG-3'; U6 5'-TGCGGGTGCTCGCTTCGGC AGC-3' (sense), and U6 5'-CCAGTGCAGGGTCCGAGGT-3' (antisense). Briefly, $100 \mathrm{ng}$ RNAs were added to a $25 \mu \mathrm{l}$ reaction system containing $12.5 \mu \mathrm{l} 2 \mathrm{X}$ master mix, $0.5 \mu 150 \mathrm{X}$ SYBR-Green, $0.5 \mu \mathrm{l}$ reverse transcription primer $(10 \mu \mathrm{M})$, $0.5 \mu \mathrm{l}$ sense and miR-183 primer $(10 \mu \mathrm{M})$. RT-qPCR was performed on a 7900HT fast RT-PCR instrument (Applied Biosystems, Singapore) using SYBR-Green for fluorophore detection. One-step RT-qPCR parameters were as follows: $37^{\circ} \mathrm{C}$ for $60 \mathrm{~min}, 10 \mathrm{~min}$ at $95^{\circ} \mathrm{C}$, followed by 40 cycles of $20 \mathrm{sec}$ at $95^{\circ} \mathrm{C}, 30 \mathrm{sec}$ at $62^{\circ} \mathrm{C}$ and $30 \mathrm{sec}$ at $72^{\circ} \mathrm{C}$. Each sample was tested three times.

For the detection of PDCD4 mRNA expression, total RNA was isolated from tissues and cells using TRIzol (Invitrogen), and cDNA was generated by reverse transcription using the PrimeScript RT-PCR kit (Takara, Japan) according to the manufacturer's instructions. The primer (GenePharma) sequences used were: PDCD4 5'-GTTGGC AGTATCCTTAGCATTGG-3' (sense), and 5'-TCCACATCA GTTGTGCTCATTAC-3' (antisense); GAPDH 5'-AAGGTC GGAGTCAACGGATT-3' (sense), and 5'-CTGGAAGAT GGTGATGGGATT-3' (antisense). GAPDH mRNA levels were used for normalization. The RT-qPCR parameters used were: $2 \mathrm{~min}$ at $95^{\circ} \mathrm{C}$, and then 40 cycles of $15 \mathrm{sec}$ at $95^{\circ} \mathrm{C}$ and $30 \mathrm{sec}$ at $60^{\circ} \mathrm{C}$. The relative expression was calculated using the relative quantification equation $(\mathrm{RQ})=2^{-\Delta \Delta \mathrm{Ct}}$ (36). Each sample was tested in triplicate.

Cell proliferation assay (MTT assay). The transfected cells were seeded in 96-well $\left(1 \times 10^{3}\right.$ cells/well) culture plates (BD Biosciences) and incubated at $37^{\circ} \mathrm{C}$ in $5 \% \mathrm{CO}_{2}$. Cell proliferation was assessed at 24, 48, 72 and $96 \mathrm{~h}$ post-transfection using the MTT assay kit (Sigma, Santa Clara, CA, USA) according to the manufacturer's instructions. Briefly, $20 \mu \mathrm{l}$ (5 mg/ml) MTT solution was added to each well. After a 4-h incubation, the medium was replaced with $150 \mu$ l dimethylsulfoxide (DMSO; Sigma). After $10 \mathrm{~min}$ of agitation (100 rpm), the absorbance at $490 \mathrm{~nm}$ of each sample was measured by a microplate spectrophotometer (Bio-Tek, Winooski, VT, USA). Experiments were performed in biological triplicate and included six replicates.

Colony formation assay. The transfected cells were seeded in 6-well ( $1 \times 10^{3}$ cells/well) culture plates (BD Biosciences). Incubation at $37^{\circ} \mathrm{C}$ with $5 \% \mathrm{CO}_{2}$ for $7-10$ days until visible cloning was observed in the dish. Subsequently, the culture medium was removed and the wells were washed twice with phosphate-buffered saline (PBS). The colonies were fixed with 
95\% ethanol for $10 \mathrm{~min}$, dried and stained with $0.1 \%$ crystal violet solution for $10 \mathrm{~min}$. Each plate was then washed three times with running water. Cell colonies with $>50$ cells were counted and photographed. The experiment was performed three times.

Cell migration and invasion assays. A wound-healing assay was used to evaluate the migratory ability of the transfected cells. The transfected cells were seeded in 6-well plates at $30 \times 10^{5}$ cells/well, and incubated until the cell monolayer reached $100 \%$ confluence. The bottom of the 6-well plates was scratched with a P200 pipette tip. Detached cells were washed with PBS and replaced with fresh medium. The scratch widths were measured at 0 and $48 \mathrm{~h}$ using an inverted microscope (50-fold). The experiment was repeated independently three times.

Transwell invasion assay performed to evaluate cell invasive ability. Transwells (Corning, Lowell, MA, USA) with a Matrigel $(2 \mathrm{mg} / \mathrm{ml})$-coated membrane containing $8-\mathrm{mm}$ diameter pores were washed with serum-free RPMI-1640. RPMI-1640 supplemented with 10\% FBS was added to the lower chamber and the Transwell filter was placed into 24-well plates. The transfected cells $\left(4 \times 10^{4}\right.$ cells/Transwell $)$ were plated in the top chamber of in $200 \mu \mathrm{l}$ serum-free RPMI-1640 with $0.1 \% \mathrm{BSA}$. After $18 \mathrm{~h}$ incubation at $37^{\circ} \mathrm{C}$ in $5 \% \mathrm{CO}_{2}$, the cells remaining on the upper membrane surface were removed using a cotton swab. The cells that invaded through the membranes were washed with PBS three times, fixed with $10 \%$ formalin and stained with $0.5 \%$ crystal violet. Five random fields for each chamber were photographed. To quantify the number of cells that had invaded, the cells were dissolved in $300 \mu 133 \%$ glacial acetic acid and the absorbance at $573 \mathrm{~nm}$ was measured using a microplate spectrophotometer.

Apoptosis assay. An apoptosis assay was used to evaluate cell apoptosis using the Annexin V-FITC/PI apoptosis detection kit (Beyotime, Jiangsu, China). After $48 \mathrm{~h}$ transfection, the cells were washed three times with ice-cold PBS, trypsinized and centrifuged. Then, 2.5 $\mu \mathrm{l}$ Annexin V-FITC reagent and $50 \mu \mathrm{l}$ $1 \mathrm{X}$ binding buffer were added to the cell groups. The cells were then incubated in the dark for $15 \mathrm{~min}$ at room temperature. Subsequently, $5 \mu \mathrm{l}$ propidium iodide (PI) and $250 \mu \mathrm{l} 1 \mathrm{X}$ binding buffer were added and the cells were incubated in the dark for $5 \mathrm{~min}$ at room temperature. The cells were gently resuspended in the Annexin $\mathrm{V}$ incubation reagent at a concentration of $10^{5}-10^{6}$ cells $/ 100 \mu \mathrm{l}$. The samples were then processed by flow cytometry (FACSCanto ${ }^{\mathrm{TM}}$ II; BD Biosciences).

Vectorconstructionanddual-luciferasereporterassay.Thewildtype 3'-UTR of PDCD4 including predicted miR-183 targeting sites was amplified using PCR amplification using the PrimerStar kit (Takara) according to the manufacturer's instructions. The primers used were: sense, 5'-TAATAAGCTACCTTTTGTAAG GCCATGTTTATTATCTAATCATTCCA-3' and antisense, 5'-TTGGAATGATTAGATAATAAACATGGCACTTACAA AAGGTAGCTTATT-3'. The mutant constructs were generated by mutation. The mutant and wild-type 3'-UTR fragments were subcloned into the XhoI site in the 3'-UTR of Renilla luciferase of the psiCHECK-2 reporter vector. The constructed vectors were designated as PDCD4-wt-vector and PDCD4-mut-vector. For the dual-luciferase reporter assays, 293T cells were seeded in 12-well plates (BD Biosciences) and cultured until the cells reached 80-90\% confluence. The PDCD4-wt-vector or PDCD4mut-vector $(0.2 \mu \mathrm{g})$ were co-transfected with $100 \mathrm{nmol} / 1 \mathrm{miR}-183$ or miRNA NC using Lipofectamine ${ }^{\mathrm{TM}} 2000$. After $36 \mathrm{~h}$ transfection, firefly and Renilla luciferase activities were measured using Dual-Luciferase reporter assay kit (Promega, Madison, WI, USA) according to the manufacturer's instructions. The firefly luciferase (FL) activity of each sample was normalized to the Renilla luciferase (RL) activity. All the experiments were performed three times.

Western blotting. The protein expression levels were analyzed by western blot analysis. Forty-eight hours post-transfection, the cells were washed twice with ice-cold PBS, RIPA lysis buffer (Beyotime) was added, and the cells were lysed on ice for $30 \mathrm{~min}$, wiped off, transferred to an EP tube and centrifuged at $12,000 \mathrm{rpm}$ for $30 \mathrm{~min}$ at $4^{\circ} \mathrm{C}$. The supernatants were collected and protein concentrations were quantified using a BCA protein assay kit (Beyotime). Each sample with $40 \mu \mathrm{g}$ protein was denatured with $5 \mathrm{X}$ sodium dodecyl sulfate (SDS) loading buffer (Beyotime) at $95^{\circ} \mathrm{C}$ for $5 \mathrm{~min}$. Subsequently, the protein samples were separated by $10 \%$ SDS-polyacrylamide gel and transferred onto PVDF membranes (both from Beyotime). The membranes were blocked with $5 \%$ fat-free milk for $1 \mathrm{~h}$, and incubated with primary antibodies PDCD4 (1:1,000 dilution; Cell Signaling Technology, Beverly, MA, USA) and $\beta$-actin (1:1,000 dilution; sc-1616-R; Santa Cruz Biotechnology, Inc., Santa Cruz, CA, USA) as a loading control overnight at $4^{\circ} \mathrm{C}$. The membranes were washed three times with PBST and incubated with horseradish peroxidase-conjugated secondary antibodies for $1 \mathrm{~h}$ at room temperature. After washing three times with PBST, immunoreactive protein bands were detected using the Odyssey scanning system (LI-COR, Lincoln, NE, USA).

Statistical analysis. Data are presented as the means \pm standard deviation (SD) from at least three separate experiments. The Student's t-test (two-tailed) was used to compare the statistical differences between the two groups using SPSS 17.0 (SPSS, Inc., Chicago, IL, USA) statistical software. $\mathrm{P}<0.05$ was considered to indicate statistically significant results.

\section{Results}

miR-183 is upregulated in papillary thyroid cancer clinical tissues and cell lines. We first determined the expression levels of miR-183 in papillary thyroid cancer and cell lines by RT-qPCR. As shown in Fig. 1A, the levels of miR-183 showed a 11.59 \pm 0.2817 -fold higher expression in cancer tissues when compared with the adjacent normal tissues $(\mathrm{P}<0.05)$. Similarly in comparison with Nthy-ori 3-1, the papillary thyroid cancer cell lines expressed higher levels of miR-183 ( $\mathrm{P}<0.05$; Fig. 1B). These results indicated that miR-183 was upregulated in papillary thyroid cancer and cell lines.

miR-183 promotes TPC-1 cell proliferation. An MTT assay was used to investigate the effects of miR-183 on papillary thyroid cancer cell proliferation. TPC-1 cells were treated 

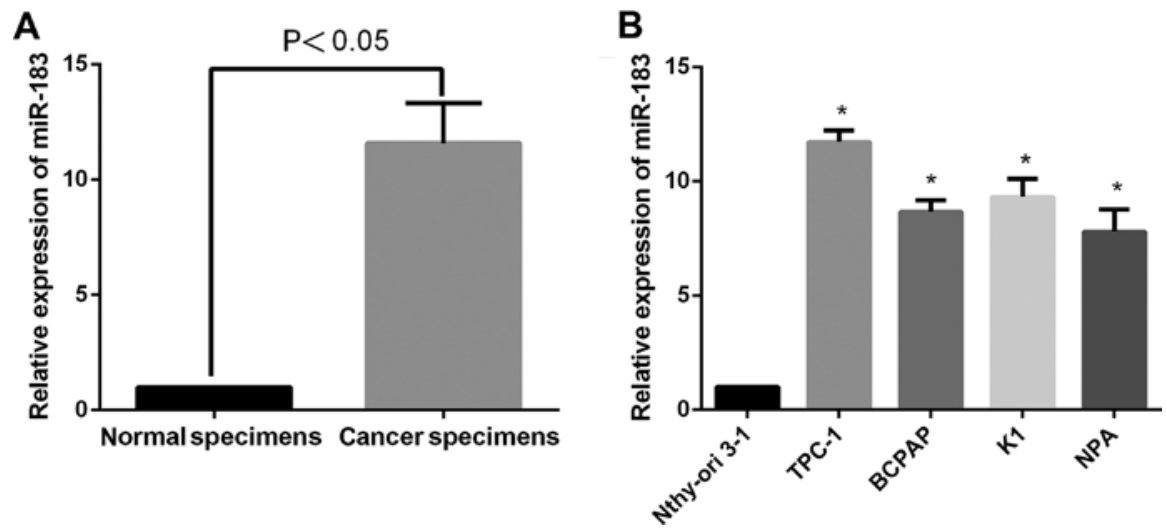

Figure 1. miR-183 is upregulated in PTC clinical tissues and cell lines. (A) Relative miR-183 expression in 38 paired PTC tissues is upregulated compared to matched adjacent normal thyroid tissues. (B) Relative expression of miR-183 is upregulated in PTC cell lines compared to Nthy-ori 3-1 cells. Data show the $2^{-\Delta \Delta \mathrm{Ct}}$ values $\pm \mathrm{SD},{ }^{*} \mathrm{P}<0.05$. PTC, papillary thyroid carcinoma
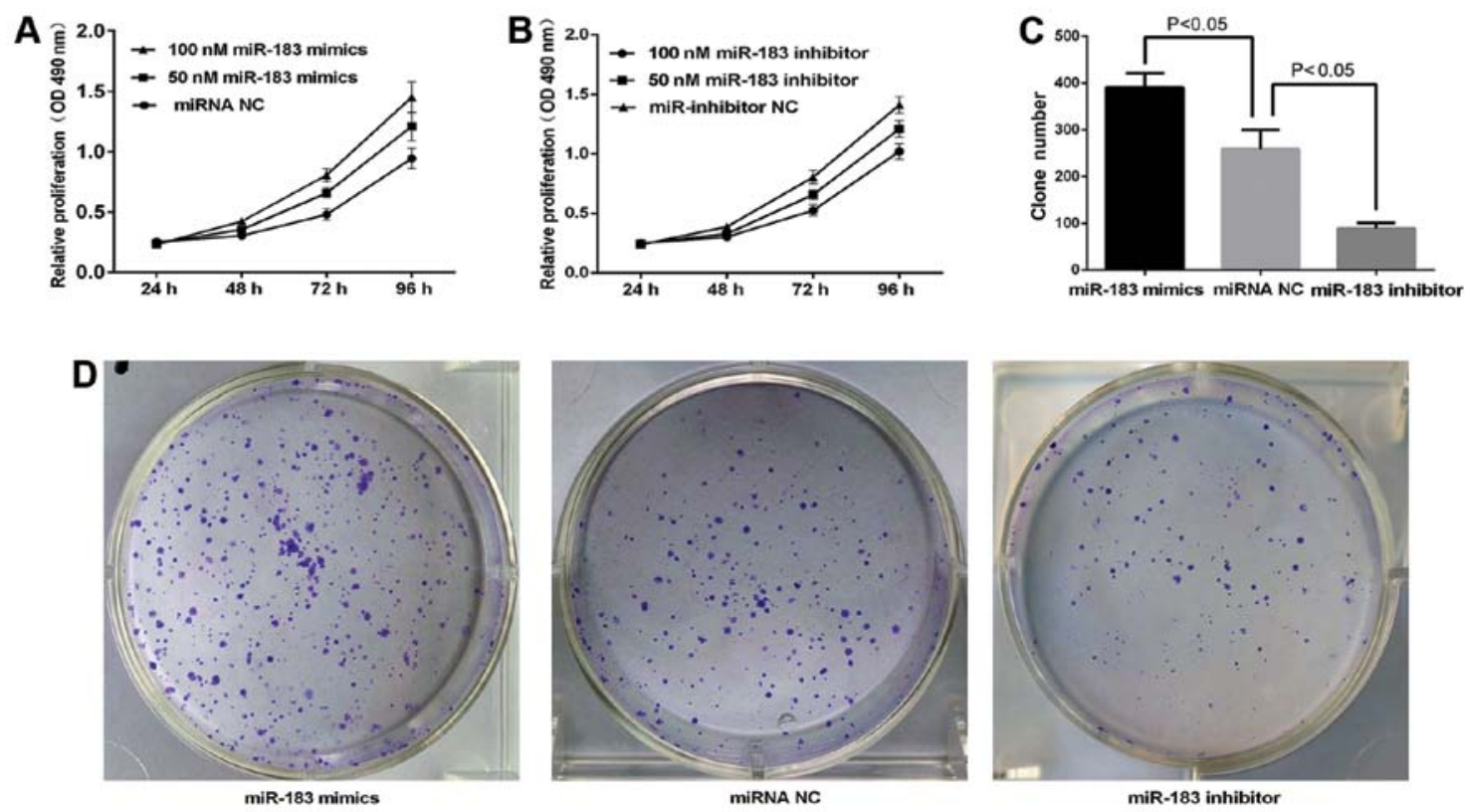

Figure 2. miR-183 promotes TPC1 cell proliferation. (A) TPC1 cells were transfected with miR-183 mimics at 50 and $100 \mathrm{nmol} / 1$ and the relative proliferation was assessed at 24, 48, 72 and $96 \mathrm{~h}$. The MTT assay showed miR-183 promoted TPC1 cell proliferation in a dose- and time-dependent manner. (B) TPC1 cells were transfected with miR-183 inhibitor at 50 and $100 \mathrm{nmol} / 1$ and the relative proliferation was assessed at 24, 48, 72 and $96 \mathrm{~h}$. The MTT assay showed the miR-183 inhibitor was inhibited TPC1 cell proliferation in a dose- and time-dependent manner. The graph shows OD $490 \mathrm{~nm} \pm \mathrm{SD}, \mathrm{P}<0.05$. (C) Cells transfected with miR-183 mimics exhibited more colonies than the NC group, while the cells transfected with miR-183 inhibitors exhibited a fewer number of colonies than the NC group. (D) Crystal violet-stained colonies from the colony formation assay for the miR-183 mimics, miRNA NC and miR-183 inhibitor groups. NC, negative control.

with 50 and $100 \mathrm{nM}$ miR-183 mimics, miR-183 inhibitor or miRNA NC for $24,48,72$ and $96 \mathrm{~h}$ and the absorbance was measured at $490 \mathrm{~nm}$. As shown in Fig. 2A, the upregulation of miR-183 significantly increased the growth rate of TPC-1 cells in a dose- and time-dependent manner $(\mathrm{P}<0.05)$. Moreover, the viability of miR-183 inhibitor groups was consistently significantly lower than that of the miRNA NC groups ( $\mathrm{P}<0.05$, Fig. 2B). Cell proliferation was markedly enhanced or inhibited when cells were treated with $100 \mathrm{nM}$ miR-183 mimics or inhibitor for $72 \mathrm{~h}$ at a growth rate of 22.32 and $34.7 \%(\mathrm{P}<0.05)$ (Fig. 2A and B). Thus, $100 \mathrm{nM}$ was used in the subsequent experiments. Increased and decreased colony formation was observed in the miR-183 and miR-183 inhibitor groups as compared to the miRNA NC group (Fig. 2D). The number of colonies for each group is shown in Fig. 2C. The clone formation of the miRNA NC group $(258.3 \pm 20.69)$ was significantly higher than that of the miR-183 inhibitor group (88.5 \pm 6.18$)$ and lower than that of the miR-183 mimics group $(390.3 \pm 15.45)(\mathrm{P}<0.05)$. The results confirmed that miR-183 promotes TPC- 1 cell proliferation.

miR-183 promotes TPC-1 cell migration and invasion. The wound-healing and Transwell invasion assays were used to determine whether miR-183 overexpression promotes tumor aggression. As shown in Fig. 3, the cells transfected with miRNA NC migrated slower than miR-183 mimics but more rapidly than the miR-183 inhibitor. The result of the Transwell assay (Fig. 4A) showed that the number of TPC-1 cells trans- 

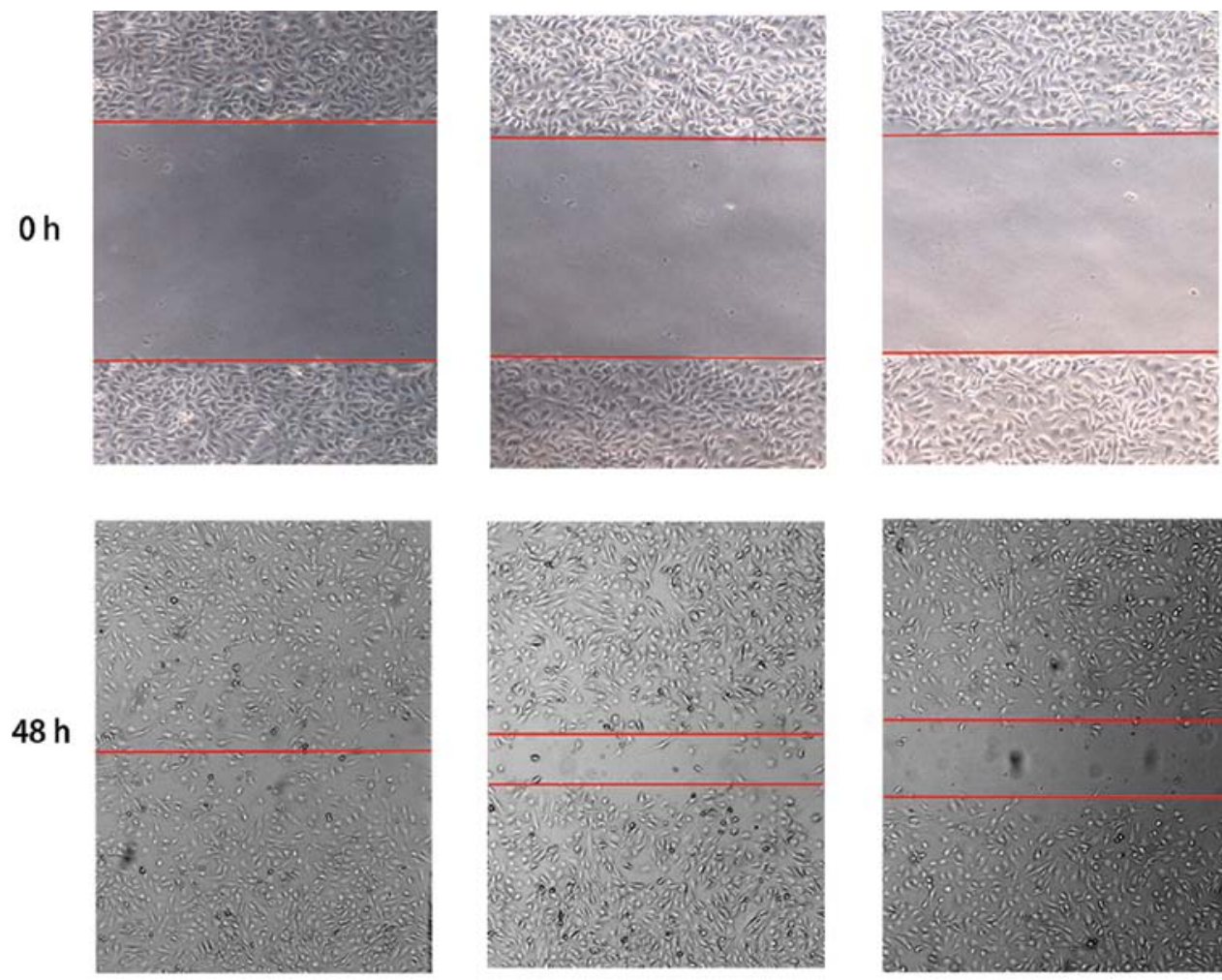

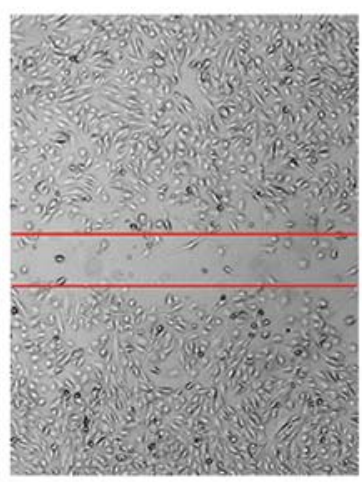

miRNA NC

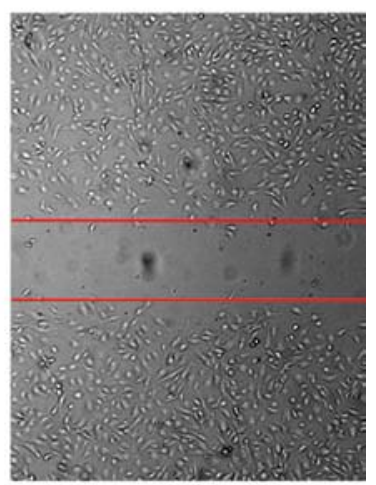

miR-183 inhibitor

Figure 3. miR-183 promotes TPC-1 cell migration. The cell-free area transfected with miR-183 inhibitors was significantly wider than that of the miRNA NC miR183 mimics group while the miR-183 mimics group cells filled in the gap after $48 \mathrm{~h}$ of the 'scratch' line being drawn on the cell monolayer. NC, negative control.

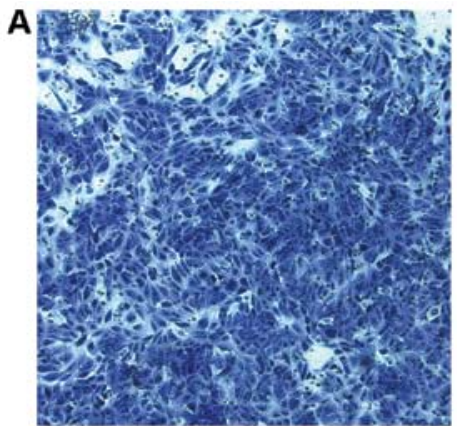

miR-183 mimics

B

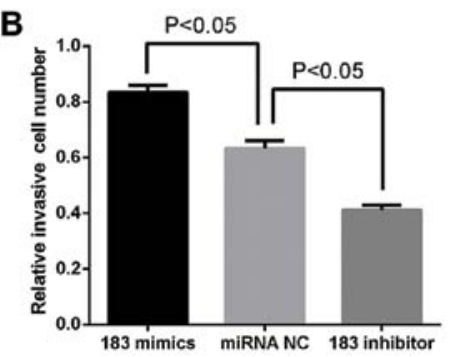

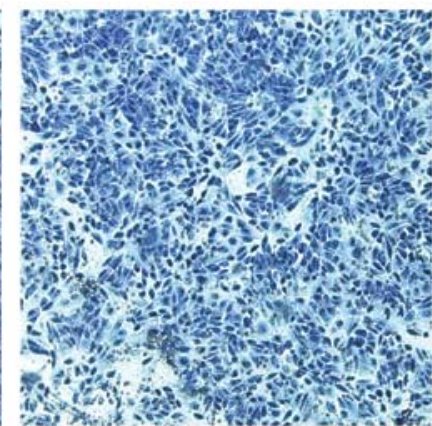

MIRNA NC

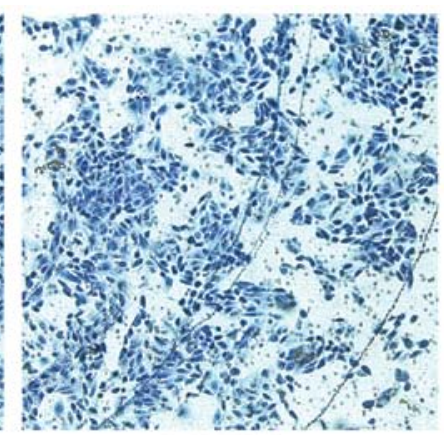

miR-183 inhibitor

Figure 4. miR-183 promotes TPC-1 cell invasion. (A) The number of TPC-1 cells transfected with miRNA NC invasion to the lower chamber was increased compared with the miR-183 inhibitor group but decreased when compared with the miR-183 mimics group. (B) Quantification of the invasive cells by solubilization of crystal violet confirmed the number of miRNA NC was increased compared to the miR-183 inhibitor group but decreased when compared with the miR-183 mimics group. Relative invasion cell number shows spectrophotometric reading at OD 573. Data are presented as mean $\pm \mathrm{SD}$, ${ }^{\text {* }} \mathrm{P}<0.05$. NC, negative control.

fected with miR-183 mimics to the lower chamber markedly increased compared with miRNA NC, whereas the number of miR-183 inhibitors markedly decreased compared with miRNA NC. The quantification results (Fig. 4B) confirmed the results observed by inverted microscopy. The OD values at $573 \mathrm{~nm}$ were: miR-183 mimics group $(0.8347 \pm 0.01431)$, miRNA NC group $(0.6327 \pm 0.01581)$ and miR-183 inhibitor group $(0.4113 \pm 0.01004)(\mathrm{P}<0.05)$. The results indicated that the overexpression of miR-183 promoted TPC-1 cell migration and invasion.

miR-183 inhibits apoptosis in TPC-1 cells. To examine whether miR-183 inhibited the apoptosis of papillary thyroid cancer cells, TPC-1 cells were transfected with $100 \mathrm{nmol} / \mathrm{l}$ 

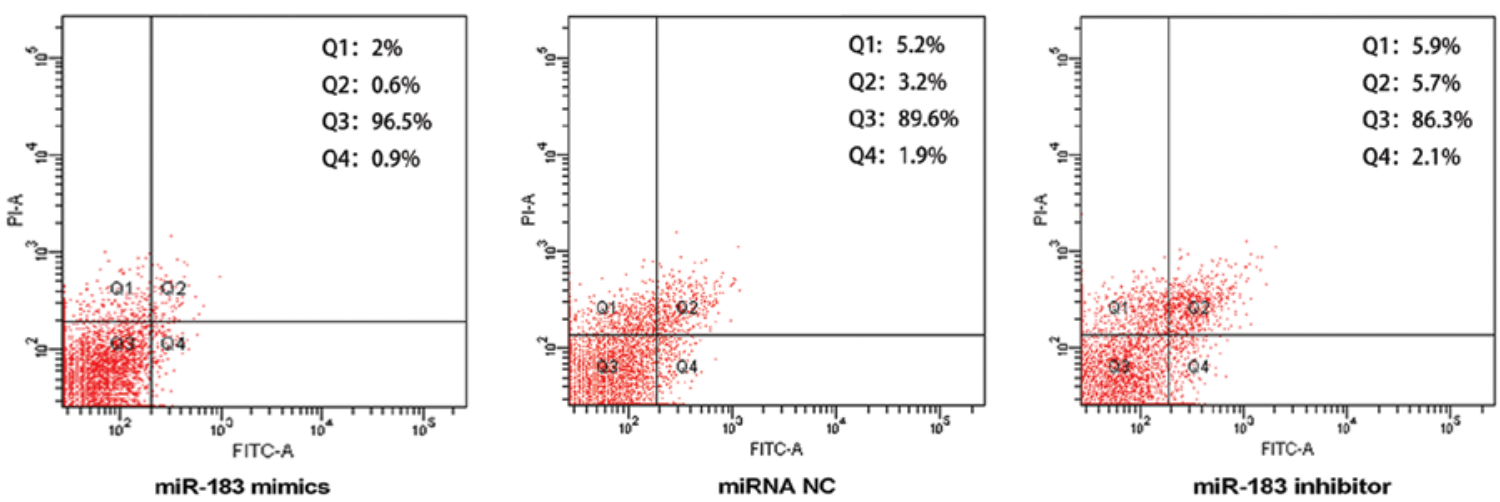

Figure 5. miR-183 mimics significantly induced early and late apoptosis of TPC1 cells. In contrast, cells transfected with negative control and inhibitors exhibited low levels of apoptosis $(\mathrm{P}<0.05)$.

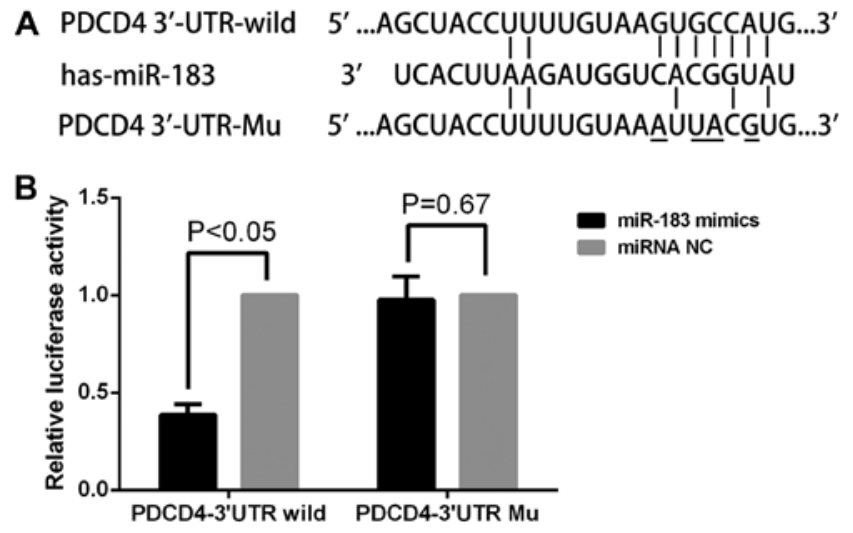

Figure 6. PDCD4 is a direct target of miR-183. (A) The miR-183 binding site in the 3'-UTR of PDCD4 mRNA and the PDCD4 3'-UTR mutant sequence. (B) The relative luciferase activity $(\mathrm{R} / \mathrm{F})$ of the miR-183 group was higher than miRNA after co-transfection with the PDCD4-wt-vector in HEK293T cells. No difference in the co-transfection with the PDCD4-mut-vector was identified.

of miR-183 mimics, miRNA NC and miR-183 inhibitor for 36 h. Flow cytometry data (Fig. 5) showed that the number of apoptotic cells was reduced in the miR-183 mimics group $(\mathrm{Q} 2+\mathrm{Q} 4=1.5 \pm 0.06 \%$ apoptotic cells) compared to the miRNA NC group $(\mathrm{Q} 2+\mathrm{Q} 4=5.1 \pm 0.08 \%$ apoptotic cells $)$ $(\mathrm{P}<0.05)$. However, the number of apoptotic cells in the miR-183 inhibitor group (Q2+Q4=7.8 $\pm 0.07 \%$ apoptotic cells) was markedly increased $(\mathrm{P}<0.05)$. These results indicated that miR-183 inhibited apoptosis in TPC-1 cells.

PDCD4 is a direct target of miR-183. To determine whether PDCD4 is a direct target of miR-183, the 3'-UTR of PDCD4 mRNA containing the miR-183 binding sites and the mutant were cloned into a luciferase reporter construct. The luciferase reporter assay (Fig. 6B) showed that the relative luciferase activity (RL/FL) of miR-183 mimics co-transfection of the PDCD4-wt-vector group was significantly decreased compared with the NC. However, this effect of miR-183 was abolished following the co-transfection of PDCD4-mut-vector. These results indicated that PDCD4 is a direct target of miR-183.

miR-183 negatively regulates PDCD4 protein expression at the post-transcriptional level. To determine the relationship

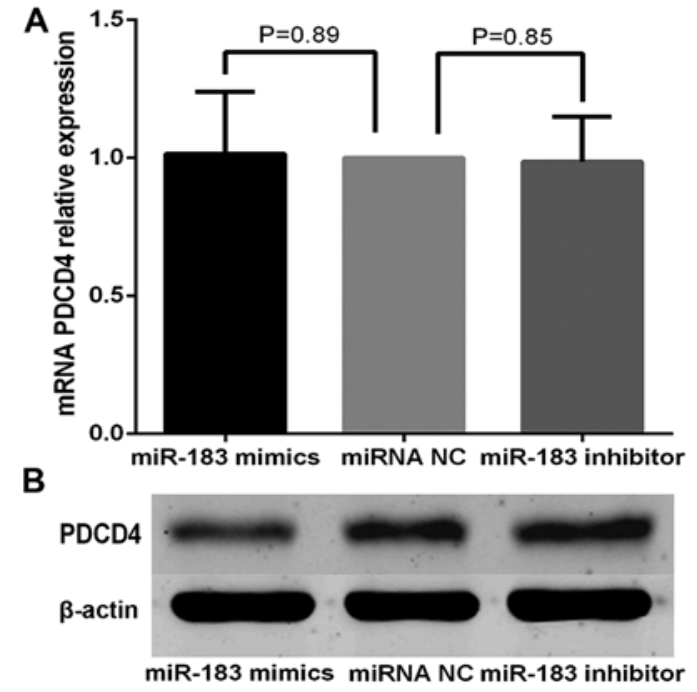

Figure 7. miR-183 negatively regulates PDCD4 protein expression at the post-transcriptional level. (A) No differences were detected in the levels of PDCD4 mRNA between miR-183 mimics, inhibitors and negative control cells, $P>0.05$. (B) Cells transfected with miR-183 mimics showed a decreased endogenous PDCD4 protein compared with miRNA NC. miR-183 inhibitors showed an enhanced PDCD4 protein expression compared with miRNA NC. NC, negative control; PDCD4, programmed cell death 4.

between miR-183 and PDCD4 at the mRNA and protein levels, miR-183 mimics, inhibitors or miRNA NC (100 nmol/l) were transfected into TPC-1 cells, and the levels of PDCD4 mRNA and protein were monitored. The RT-qPCR analysis showed that PDCD4 mRNA levels were not significantly altered during these treatments (Fig. 7A). However, western blot analysis revealed that compared to the controls, the expression of PDCD4 was significantly reduced by miR-183 mimics transfection and increased by miR-183 inhibitor transfection (Fig. 7B). The results indicated that miR-183 did not affect mRNA stability and regulated PDCD4 expression at the post-transcriptional level.

PDCD4 is involved in miR-183-induced effects in PTC cells. To determine whether PDCD4 serves as a critical mediator of the role of miR-183 in PTC cells, PDCD4 and NC siRNAs were transfected into TPC-1 cells. As shown in Fig. 8H, the protein level of PDCD4 was decreased in TPC-1 cells transfected with 

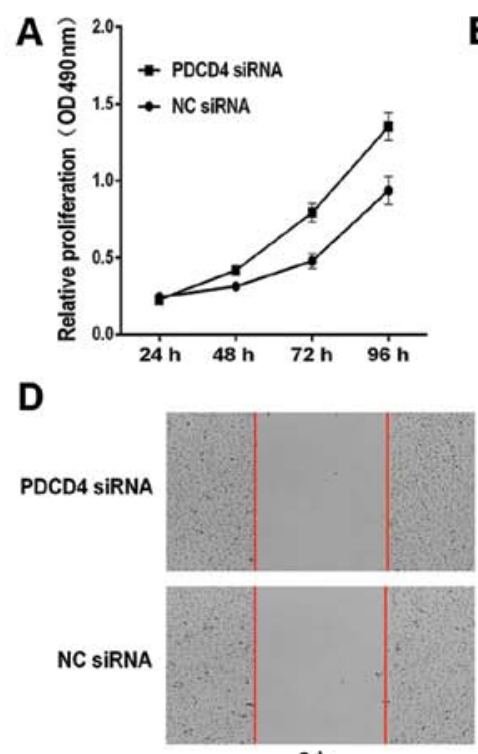

$\mathrm{Oh}$

F

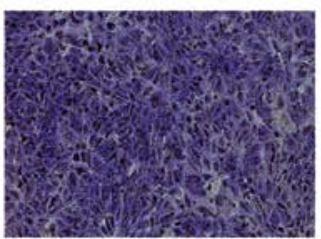

PDCD4 SiRNA
B
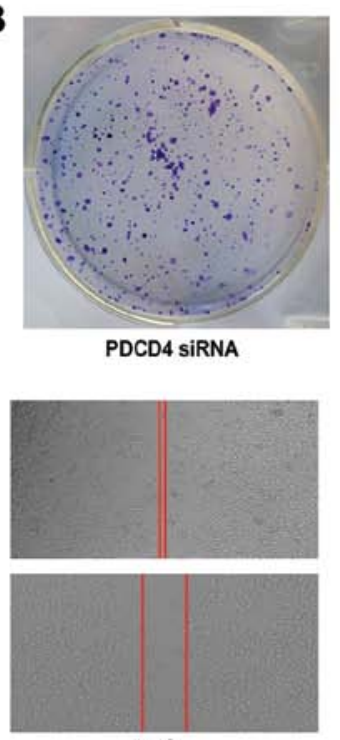

$48 \mathrm{~h}$

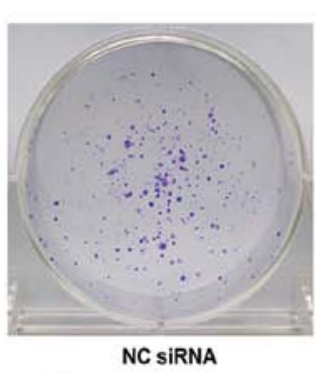

E
C

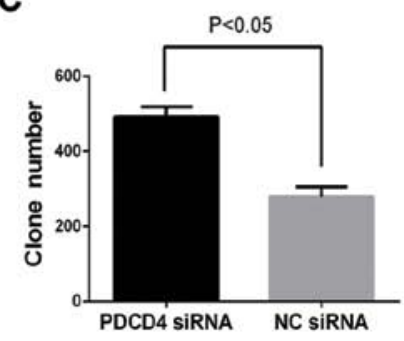

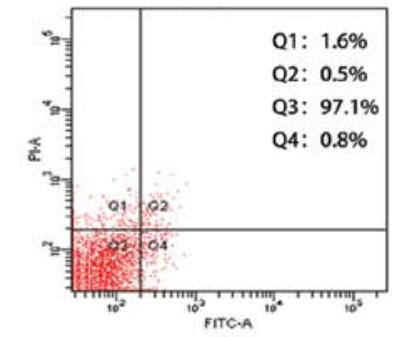

PDCD4 SIRNA
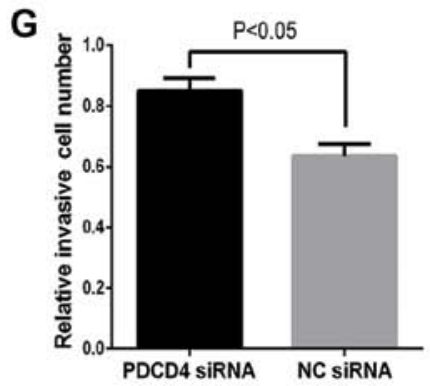

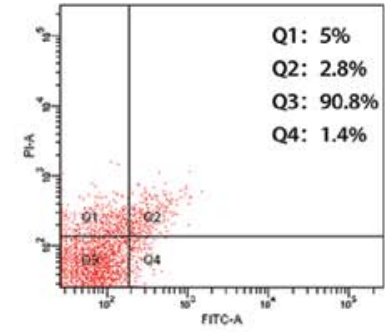

NC SIRNA
H

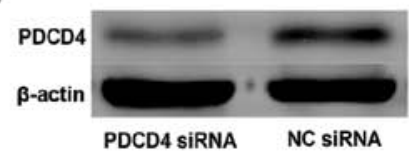

Figure 8. Effects of PDCD4 in TPC1 cells promotes proliferation, migration, invasion and inhibits apoptosis. (A) Cells transfected with PDCD4 siRNA showed markedly increased cell proliferation compared with NC siRNA $(\mathrm{P}<0.05)$. (B and $\mathrm{C})$ Cells transfected with PDCD4 siRNA exhibited more colonies than the siRNA NC group $(\mathrm{P}<0.05)$. ( $\mathrm{D}, \mathrm{F}$ and $\mathrm{G}) \mathrm{PDCD} 4$ siRNA promotes TPC-1 cell migration and invasion $(\mathrm{P}<0.05)$. (E) Inhibition of PDCD4 decreased the ability of cells to undergo apoptosis $(\mathrm{P}<0.05)$. $(\mathrm{H})$ The level of PDCD4 protein was decreased in the PDCD4 siRNA group compared with the siRNA NC group. NC, negative control; PDCD4, programmed cell death 4.

PDCD4 siRNA compared with NC siRNA. In the MTT assay, compared with the NC siRNA group, the PDCD4 siRNA group markedly increased cell proliferation by 33.4, 65.4 and $44.4 \%$ at 48, 72 and $96 \mathrm{~h}$, respectively $(\mathrm{P}<0.05$; Fig. 8A). Moreover, cell colony formation efficiency increased in the PDCD4 siRNA group $(\mathrm{P}<0.05$ Fig. 8B and $\mathrm{C})$. Knockdown of PDCD4 promoted the migration and invasion ability of TPC-1 cells $(\mathrm{P}<0.05$; Fig. 8D, E and $\mathrm{G})$. The apoptosis assay demonstrated knockdown of PDCD4 decreased TPC-1 cell apoptosis by $90 \%$ at $36 \mathrm{~h}$ after transfection (Fig. 8F). These data indicated that effects of siRNA versus PDCD4 were similar to those induced by miR-183 in TPC-1 cells, rendering PDCD4 as a functional target of miR-183.

\section{Discussion}

Mounting evidence has indicated that miRNAs contribute to cancer pathogenesis. Thus, understanding the relationship between miRNAs and its targets and cell signaling pathways involved in cancer became important. miR-183 is a member of the miR-183-96-182 cluster, located at the human 7q31-34 locus and which contains highly conserved sequences (37-40). It has been found to be dysregulated in a variety of different solid tumors. miR-183 is downregulated in lung cancer cells (41), osteosarcoma $(42,43)$ and breast cancer $(44)$. However, it is upregulated in prostate cancer $(39,45-47)$, hepatocellular carcinoma (HCC) (48-50), colon cancer $(38,51-54)$ and medullary thyroid carcinoma (55). The different expression profiles may be tissue- and cell type-specific. The abovementioned studies reported that miR-183 is involved in cell differentiation, proliferation, migration, invasion and apoptosis. This finding suggested that miR-183 plays a critical role in tumorigenesis and serves as an oncogene or tumor-suppressor gene in several types of cancer. However, the exact role of miR-183 in PTC is not fully understood.

In the present study, we determined that the expression level of miR-183 was significantly upregulated in PTC tissues and the Nthy-ori 3-1 cell line compared with adjacent normal tissues and the four PTC cell lines. The functional assays demonstrated that overexpression of miR-183 markedly promoted proliferation, migration, invasion and suppressed the apoptosis of TPC-1 cells. These results suggest that miR-183 functions as an oncogene in TPC.

Many targets of miRNA-183 have been identified including ezrin $(41,43,56,57)$, VIL2 (44), EGR1 (38), SMAD4, Dkk-3 (40), LRP6 (58), IDH2 (59), ITGB1, KIF2A (60) and Tiam1 (61). Although PDCD4 was identified as one of the targets of miR-183 in human HCC cells (34) and oesophageal 
squamous cell carcinoma (35), the effect of miR-183 on PTC through the PDCD4 pathway was unknown.

The PDCD4 gene is located at chromosome 10q24 and was first isolated from a human glioma cDNA library as a tumor-associated gene $(62,63)$. Previous results indicated that PDCD4 expression is downregulated or lost in several tumor types as a novel tumor suppressor (24,25,64-67). Additionally, PDCD4 is involved in tumor progression: cell proliferation, invasion, metastasis and neoplastic transformation in breast cancer (67-69); proliferation and invasion in esophageal squamous cell carcinoma (70); invasion, intravasation and metastasis in colon cancer (71); and cell proliferation, invasion and apoptosis in TPC-1 (32). The abovementioned data suggested that PDCD4 is a critical regulator in many human malignancies.

The PDCD4 protein influences protein translation by binding eukaryotic translation initiation factor 4A (eIF4A) $(72,73)$ and reducing growth advantages of the cells and development of cancer by inhibiting activator protein 1 (AP-1)-mediated transactivation (74). Another protein that is regulated by PDCD4 is carbonic anhydrase type II (CA II) (75), which contributes to the tumor-suppressor function. PDCD4 inhibits tumor cell invasion and metastasis by downregulating urokinase receptor (UPAR) which mediates the degradation of extracellular matrix components (74). In addition, PDCD4 influences cell cycle progression by inducing p21Waf1/Cip1 (25). PDCD4 has also been found to be involved in the PI3K/AKT pathway (76), $\beta$-catenin, and T-cell factor pathway (77). Moreover, PDCD4 can be induced by the cyclooxygenase-2 (COX-2) inhibitor, retinoic acid receptor (RAR) agonists (78), transforming growth factor- $\beta$ (TGF- $\beta$ ) (66), and be downregulated by miR-21 $(71,79,80)$.

In the present study, the luciferase reporter assay confirmed that PDCD4 was a direct target of miR-183. Additionally, the knockdown of PDCD4 by siRNA in PTC1 cells significantly enhanced cell proliferation, migration and invasion and reduced apoptosis, consistent with the results of teh overexpression miR-183 in PTC1 cells. The western blot analysis revealed that protein was decreased in TPC-1 cells following the upregulation of miR-183. These findings suggest that PDCD4 was an important target of miR-183 in the TPC-1 cell line. miR-183 regulates cell functions by directly targeting PDCD4 in PTC1 cells. Furthermore, RT-qPCR results showed no differences in miR-183 overexpressing cells in PDCD4 mRNA levels. These results indicate that miR-183 negatively regulates endogenous PDCD4 protein expression at the post-transcriptional level but not at the mRNA level.

In summary, the present study has demonstrated that miR-183 was upregulated in TPC tissues and cell lines, and was able to promote cell proliferation, migration, invasion and suppress apoptosis by negatively regulating the expression of PDCD4 protein at the post-transcriptional level in TPC-1 cells. Therefore, the findings of the present study reveal a viable approach for the diagnosis of PTC, and provide a novel molecular target for PTC therapy.

\section{Acknowledgements}

This study was made possible with financial support from the National Natural Sciences Foundation of China (no. 81272240), and the Institutional Ethics Committee of Shanghai Tenth People's Hospital. Furthermore, we extend special thanks to all the teachers at the Central Laboratory of the Shanghai Tenth People's hospital for their assistance and support.

\section{References}

1. Leenhardt L, Grosclaude P, Chérié-Challine L; Thyroid Cancer Committee: Increased incidence of thyroid carcinoma in France: A true epidemic or thyroid nodule management effects? Report from the French Thyroid Cancer Committee. Thyroid 14: 1056-1060, 2004.

2. Davies L and Welch HG: Increasing incidence of thyroid cancer in the United States, 1973-2002. JAMA 295: 2164-2167, 2006.

3. Schmid KW: Molecular pathology of thyroid tumors. Pathologe 31 (Suppl 2): 229-233, 2010 (In German).

4. Siegel R, Naishadham D and Jemal A: Cancer statistics for Hispanics/Latinos, 2012. CA Cancer J Clin 62: 283-298, 2012.

5. Loh KC, Greenspan FS, Gee L, Miller TR and Yeo PP: Pathological tumor-node-metastasis (pTNM) staging for papillary and follicular thyroid carcinomas: A retrospective analysis of 700 patients. J Clin Endocrinol Metab 82: 3553-3562, 1997.

6. Chi SW, Zang JB, Mele A and Darnell RB: Argonaute HITS-CLIP decodes microRNA-mRNA interaction maps. Nature 460: 479-486, 2009.

7. Hale BJ, Yang CX and Ross JW: Small RNA regulation of reproductive function. Mol Reprod Dev 81: 148-159, 2014.

8. Bartel DP: MicroRNAs: Genomics, biogenesis, mechanism, and function. Cell 116: 281-297, 2004.

9. Vohradsky J, Panek J and Vomastek T: Numerical modelling of microRNA-mediated mRNA decay identifies novel mechanism of microRNA controlled mRNA downregulation. Nucleic Acids Res 38: 4579-4585, 2010.

10. Chu $\mathrm{C}$ and Zhao Z: MicroRNA in the molecular mechanism of the circadian clock in mammals. Front Biosci 18: 441-446, 2013.

11. Miska EA: How microRNAs control cell division, differentiation and death. Curr Opin Genet Dev 15: 563-568, 2005.

12. Hwang HW and Mendell JT: MicroRNAs in cell proliferation, cell death, and tumorigenesis. Br J Cancer 94: 776-780, 2006.

13. Calin GA and Croce CM: MicroRNA signatures in human cancers. Nat Rev Cancer 6: 857-866, 2006.

14. Dykxhoorn DM: MicroRNAs and metastasis: Little RNAs go a long way. Cancer Res 70: 6401-6406, 2010.

15. Calin GA, Sevignani C, Dumitru CD, Hyslop T, Noch E, Yendamuri S, Shimizu M, Rattan S, Bullrich F, Negrini M, et al: Human microRNA genes are frequently located at fragile sites and genomic regions involved in cancers. Proc Natl Acad Sci USA 101: 2999-3004, 2004.

16. Gao Y, Wang C, Shan Z, Guan H, Mao J, Fan C, Wang H, Zhang $\mathrm{H}$ and Teng $\mathrm{W}$ : miRNA expression in a human papillary thyroid carcinoma cell line varies with invasiveness. Endocr J 57: 81-86, 2010.

17. Menon MP and Khan A: Micro-RNAs in thyroid neoplasms: Molecular, diagnostic and therapeutic implications. J Clin Pathol 62: 978-985, 2009.

18. Nikiforova MN, Chiosea SI and Nikiforov YE: MicroRNA expression profiles in thyroid tumors. Endocr Pathol 20: 85-91, 2009.

19. Srivastava A, Goldberger H, Dimtchev A, Ramalinga M, Chijioke J, Marian C, Oermann EK, Uhm S, Kim JS, Chen LN, et al: MicroRNA profiling in prostate cancer - the diagnostic potential of urinary miR-205 and miR-214. PLoS One 8: e76994, 2013.

20. Hodge LS, Elsawa SF, Grote DM, Price-Troska TL, Asmann YW, Fonseca R, Gertz MA, Witzig TE, Novak AJ and Ansell SM: MicroRNA expression in tumor cells from Waldenstrom's macroglobulinemia reflects both their normal and malignant cell counterparts. Blood Cancer J 1: e24, 2011.

21. He H, Jazdzewski K, Li W, Liyanarachchi S, Nagy R, Volinia S, Calin GA, Liu CG, Franssila K, Suster S, et al: The role of microRNA genes in papillary thyroid carcinoma. Proc Natl Acad Sci USA 102: 19075-19080, 2005.

22. Tetzlaff MT, Liu A, Xu X, Master SR, Baldwin DA, Tobias JW, Livolsi VA and Baloch ZW: Differential expression of miRNAs in papillary thyroid carcinoma compared to multinodular goiter using formalin fixed paraffin embedded tissues. Endocr Pathol 18: 163-173, 2007. 
23. Pallante $\mathrm{P}$, Visone R, Ferracin M, Ferraro A, Berlingieri MT, Troncone G, Chiappetta G, Liu CG, Santoro M, Negrini M, et al MicroRNA deregulation in human thyroid papillary carcinomas. Endocr Relat Cancer 13: 497-508, 2006.

24. Jansen AP, Camalier CE, Stark C and Colburn NH: Characterization of programmed cell death 4 in multiple human cancers reveals a novel enhancer of drug sensitivity. Mol Cancer Ther 3: 103-110, 2004.

25. Göke R, Barth P, Schmidt A, Samans B and Lankat-Buttgereit B: Programmed cell death protein 4 suppresses CDK1/cde2 via induction of $\mathrm{p} 21^{\text {Waf } 1 / \text { Cipl }}$. Am J Physiol Cell Physiol 287: C1541-C1546, 2004

26. Vikhreva PN, Shepelev MV, Korobko EV and Korobko IV: Pdcd4 tumor suppressor: Properties, functions, and their application to oncology. Mol Gen Mikrobiol Virusol 2: 3-11, 2010 (In Russian)

27. Young MR, Santhanam AN, Yoshikawa N and Colburn NH: Have tumor suppressor PDCD4 and its counteragent oncogenic miR-21 gone rogue? Mol Interv 10: 76-79, 2010.

28. Allgayer $\mathrm{H}$ : Pdcd4, a colon cancer prognostic that is regulated by a microRNA. Crit Rev Oncol Hematol 73: 185-191, 2010.

29. Fassan M, Pizzi M, Battaglia G, Giacomelli L, Parente P Bocus P, Ancona E and Rugge M: Programmed cell death 4 (PDCD4) expression during multistep Barrett's carcinogenesis. J Clin Pathol 63: 692-696, 2010.

30. Fassan M, Pizzi M, Giacomelli L, Mescoli C, Ludwig K, Pucciarelli S and Rugge M: PDCD4 nuclear loss inversely correlates with miR-21 levels in colon carcinogenesis. Virchows Arch 458: 413-419, 2011.

31. Fassan M, Realdon S, Pizzi M, Balistreri M, Battaglia G, Zaninotto G, Ancona E and Rugge M: Programmed cell death 4 nuclear loss and miR-21 or activated Akt overexpression in esophageal squamous cell carcinogenesis. Dis Esophagus 25: 263-268, 2012

32. Zhang J, Yang Y, Liu Y, Fan Y, Liu Z, Wang X, Yuan Q, Yin Y, Yu J, Zhu M, et al: MicroRNA-21 regulates biological behaviors in papillary thyroid carcinoma by targeting programmed cell death 4. J Surg Res 189: 68-74, 2014.

33. Pennelli G, Fassan M, Mian C, Pizzi M, Balistreri M, Barollo S, Galuppini F, Guzzardo V, Pelizzo M and Rugge M: PDCD4 expression in thyroid neoplasia. Virchows Arch 462: 95-100, 2013.

34. Li J, Fu H, Xu C, Tie Y, Xing R, Zhu J, Qin Y, Sun Z and Zheng X: miR-183 inhibits TGF-beta1-induced apoptosis by downregulation of PDCD4 expression in human hepatocellular carcinoma cells. BMC Cancer 10: 354, 2010.

35. Ren LH, Chen WX, Li S, He XY, Zhang ZM, Li M, Cao RS, Hao B, Zhang HJ, Qiu HQ, et al: MicroRNA-183 promotes proliferation and invasion in oesophageal squamous cell carcinoma by targeting programmed cell death 4. Br J Cancer 111: 2003-2013, 2014.

36. Livak KJ and Schmittgen TD: Analysis of relative gene expression data using real-time quantitative PCR and the $2^{-\Delta \Delta C}$ Tethod. Methods 25: 402-408, 2001.

37. Bastian BC, LeBoit PE, Hamm H, Bröcker EB and Pinkel D: Chromosomal gains and losses in primary cutaneous melanomas detected by comparative genomic hybridization. Cancer Res 58 2170-2175, 1998

38. Sarver AL, Li L and Subramanian S: MicroRNA miR-183 functions as an oncogene by targeting the transcription factor EGR1 and promoting tumor cell migration. Cancer Res 70 9570-9580, 2010.

39. Mihelich BL, Khramtsova EA, Arva N, Vaishnav A, Johnson DN, Giangreco AA, Martens-Uzunova E, Bagasra O, KajdacsyBalla A and Nonn L: miR-183-96-182 cluster is overexpressed in prostate tissue and regulates zinc homeostasis in prostate cells. J Biol Chem 286: 44503-44511, 2011

40. Ueno K, Hirata H, Shahryari V, Deng G, Tanaka Y, Tabatabai ZL, Hinoda $\mathrm{Y}$ and Dahiya R: microRNA-183 is an oncogene targeting Dkk-3 and SMAD4 in prostate cancer. Br J Cancer 108: $1659-1667,2013$

41. Wang G, Mao W and Zheng S: MicroRNA-183 regulates Ezrin expression in lung cancer cells. FEBS Lett 582: 3663-3668, 2008

42. Mu Y, Zhang $\mathrm{H}$, Che L and Li K: Clinical significance of microRNA-183/Ezrin axis in judging the prognosis of patients with osteosarcoma. Med Oncol 31: 821, 2014

43. Zhu J, Feng Y, Ke Z, Yang Z, Zhou J, Huang X and Wang L: Down-regulation of miR-183 promotes migration and invasion of osteosarcoma by targeting Ezrin. Am J Pathol 180: 2440-2451, 2012.
44. Lowery AJ, Miller N, Dwyer RM and Kerin MJ: Dysregulated miR-183 inhibits migration in breast cancer cells. BMC Cancer 10: 502, 2010.

45. Tsuchiyama K, Ito $H$, Taga M, Naganuma S, Oshinoya $Y$, Nagano K, Yokoyama O and Itoh $\mathrm{H}$ : Expression of microRNAs associated with Gleason grading system in prostate cancer: miR-182-5p is a useful marker for high grade prostate cancer. Prostate 73: 827-834, 2013

46. Schaefer A, Jung M, Mollenkopf HJ, Wagner I, Stephan C, Jentzmik F, Miller K, Lein M, Kristiansen $G$ and Jung K: Diagnostic and prognostic implications of microRNA profiling in prostate carcinoma. Int J Cancer 126: 1166-1176, 2010 .

47. Larne O, Martens-Uzunova E, Hagman Z, Edsjö A, Lippolis G, den Berg MS, Bjartell A, Jenster G and Ceder Y: miQ - a novel microRNA based diagnostic and prognostic tool for prostate cancer. Int J Cancer 132: 2867-2875, 2013.

48. Goeppert B, Schmezer P, Dutruel C, Oakes C, Renner M, Breinig M, Warth A, Vogel MN, Mittelbronn M, Mehrabi A, et al: Down-regulation of tumor suppressor A kinase anchor protein 12 in human hepatocarcinogenesis by epigenetic mechanisms. Hepatology 52: 2023-2033, 2010.

49. Liu AM, Yao TJ, Wang W, Wong KF, Lee NP, Fan ST, Poon RT, Gao C and Luk JM: Circulating miR-15b and miR-130b in serum as potential markers for detecting hepatocellular carcinoma: A retrospective cohort study. BMJ Open 2: e000825, 2012

50. Liang Z, Gao Y, Shi W, Zhai D, Li S, Jing L, Guo H, Liu T, Wang Y and Du Z: Expression and significance of microRNA-183 in hepatocellular carcinoma. Sci World J 2013: 381874, 2013

51. Sarver AL, French AJ, Borralho PM, Thayanithy V, Oberg AL, Silverstein KA, Morlan BW, Riska SM, Boardman LA, Cunningham JM, et al: Human colon cancer profiles show differential microRNA expression depending on mismatch repair status and are characteristic of undifferentiated proliferative states. BMC Cancer 9: 401, 2009.

52. Motoyama K, Inoue H, Takatsuno Y, Tanaka F, Mimori K, Uetake H, Sugihara K and Mori M: Over- and under-expressed microRNAs in human colorectal cancer. Int $\mathbf{J}$ Oncol 34: 1069-1075, 2009

53. Earle JS, Luthra R, Romans A, Abraham R, Ensor J, Yao H and Hamilton SR: Association of microRNA expression with microsatellite instability status in colorectal adenocarcinoma. J Mol Diagn 12: 433-440, 2010.

54. Li X, Zhang G, Luo F, Ruan J, Huang D, Feng D, Xiao D, Zeng Z, Chen $\mathrm{X}$ and $\mathrm{Wu} \mathrm{W}$ : Identification of aberrantly expressed miRNAs in rectal cancer. Oncol Rep 28: 77-84, 2012.

55. Mian C, Pennelli G, Fassan M, Balistreri M, Barollo S, Cavedon E, Galuppini F, Pizzi M, Vianello F, Pelizzo MR, et al: MicroRNA profiles in familial and sporadic medullary thyroid carcinoma: Preliminary relationships with RET status and outcome. Thyroid 22: 890-896, 2012.

56. Zhao H, Guo M, Zhao G, Ma Q, Ma B, Qiu X and Fan Q: miR-183 inhibits the metastasis of osteosarcoma via downregulation of the expression of Ezrin in F5M2 cells. Int J Mol Med 30: 1013-1020, 2012.

57. Li J, Liang SH and Lu X: Potential role of ezrin and its related microRNA in ovarian cancer invasion and metastasis. Zhonghua Fu Chan Ke Za Zhi 45: 787-792, 2010 (In Chinese).

58. Wang J, Wang X, Li Z, Liu H and Teng Y: MicroRNA-183 suppresses retinoblastoma cell growth, invasion and migration by targeting LRP6. FEBS J 281: 1355-1365, 2014.

59. Tanaka H, Sasayama T, Tanaka K, Nakamizo S, Nishihara M, Mizukawa K, Kohta M, Koyama J, Miyake S, Taniguchi M, et al: MicroRNA-183 upregulates HIF-1 $\alpha$ by targeting isocitrate dehydrogenase 2 (IDH2) in glioma cells. J Neurooncol 111: 273-283, 2013.

60. Li G, Luna C, Qiu J, Epstein DL and Gonzalez P: Targeting of integrin betal and kinesin 2alpha by microRNA 183. J Biol Chem 285: 5461-5471, 2010.

61. Li J, Liang S, Jin H, Xu C, Ma D and Lu X: Tiam1, negatively regulated by $\mathrm{miR}-22$, miR-183 and $\mathrm{miR}-31$, is involved in migration, invasion and viability of ovarian cancer cells. Oncol Rep 27: 1835-1842, 2012.

62. Soejima H, Miyoshi O, Yoshinaga H, Masaki Z, Ozaki I, Kajiwara S, Niikawa N, Matsuhashi S and Mukai T: Assignment of the programmed cell death 4 gene (PDCD4) to human chromosome band $10 \mathrm{q} 24$ by in situ hybridization. Cytogenet Cell Genet 87: 113-114, 1999. 
63. Cmarik JL, Min H, Hegamyer G, Zhan S, Kulesz-Martin M, Yoshinaga H, Matsuhashi S and Colburn NH: Differentially expressed protein Pdcd4 inhibits tumor promoter-induced neoplastic transformation. Proc Natl Acad Sci USA 96: 14037-14042, 1999.

64. Young MR, Yang HS and Colburn NH: Promising molecular targets for cancer prevention: AP-1, NF-kappa B and Pdcd4. Trends Mol Med 9: 36-41, 2003.

65. Afonja O, Juste D, Das S, Matsuhashi S and Samuels HH: Induction of PDCD4 tumor suppressor gene expression by RAR agonists, antiestrogen and HER-2/neu antagonist in breast cancer cells. Evidence for a role in apoptosis. Oncogene 23: 8135-8145, 2004.

66. Zhang H, Ozaki I, Mizuta T, Hamajima H, Yasutake T, Eguchi Y, Ideguchi $\mathrm{H}$, Yamamoto $\mathrm{K}$ and Matsuhashi S: Involvement of programmed cell death 4 in transforming growth factorbeta1-induced apoptosis in human hepatocellular carcinoma. Oncogene 25: 6101-6112, 2006.

67. Frankel LB, Christoffersen NR, Jacobsen A, Lindow M, Krogh A and Lund AH: Programmed cell death 4 (PDCD4) is an important functional target of the microRNA miR-21 in breast cancer cells. J Biol Chem 283: 1026-1033, 2008.

68. Zhu S, Wu H, Wu F, Nie D, Sheng S and Mo YY: MicroRNA-21 targets tumor suppressor genes in invasion and metastasis. Cell Res 18: 350-359, 2008.

69. Lu Z, Liu M, Stribinskis V, Klinge CM, Ramos KS, Colburn NH and $\mathrm{Li} \mathrm{Y}$ : MicroRNA-21 promotes cell transformation by targeting the programmed cell death 4 gene. Oncogene 27 : 4373-4379, 2008.

70. Hiyoshi Y, Kamohara H, Karashima R, Sato N, Imamura Y, Nagai Y, Yoshida N, Toyama E, Hayashi N, Watanabe M, et al: MicroRNA-21 regulates the proliferation and invasion in esophageal squamous cell carcinoma. Clin Cancer Res 15: 1915-1922, 2009.

71. Asangani IA, Rasheed SA, Nikolova DA, Leupold JH, Colburn NH, Post S and Allgayer H: MicroRNA-21 (miR-21) post-transcriptionally downregulates tumor suppressor Pdcd4 and stimulates invasion, intravasation and metastasis in colorectal cancer. Oncogene 27: 2128-2136, 2008.
72. Göke A, Göke R, Knolle A, Trusheim H, Schmidt H, Wilmen A, Carmody R, Göke B and Chen YH: DUG is a novel homologue of translation initiation factor $4 \mathrm{G}$ that binds eIF4A. Biochem Biophys Res Commun 297: 78-82, 2002.

73. Yang HS, Jansen AP, Komar AA, Zheng X, Merrick WC, Costes S, Lockett SJ, Sonenberg N and Colburn NH: The transformation suppressor Pdcd4 is a novel eukaryotic translation initiation factor 4A binding protein that inhibits translation. Mol Cell Biol 23: 26-37, 2003.

74. Leupold JH, Yang HS, Colburn NH, Asangani I, Post S and Allgayer H: Tumor suppressor Pdcd4 inhibits invasion/intravasation and regulates urokinase receptor (u-PAR) gene expression via Sp-transcription factors. Oncogene 26: 4550-4562, 2007.

75. Lankat-Buttgereit B, Gregel C, Knolle A, Hasilik A, Arnold R and Göke R: Pdcd4 inhibits growth of tumor cells by suppression of carbonic anhydrase type II. Mol Cell Endocrinol 214: 149-153, 2004.

76. Wang WQ, Zhang H, Wang HB, Sun YG, Peng ZH, Zhou G, Yang SM, Wang RQ and Fang DC: Programmed cell death 4 (PDCD4) enhances the sensitivity of gastric cancer cells to TRAIL-induced apoptosis by inhibiting the PI3K/Akt signaling pathway. Mol Diagn Ther 14: 155-161, 2010.

77. Wang Q, Sun Z and Yang HS: Downregulation of tumor suppressor Pdcd4 promotes invasion and activates both betacatenin/Tcf and AP-1-dependent transcription in colon carcinoma cells. Oncogene 27: 1527-1535, 2008.

78. Zhang Z and DuBois RN: Detection of differentially expressed genes in human colon carcinoma cells treated with a selective COX-2 inhibitor. Oncogene 20: 4450-4456, 2001.

79. Yang Y, Meng H, Peng Q, Yang X, Gan R, Zhao L, Chen Z, $\mathrm{Lu} \mathrm{J}$ and Meng QH: Downregulation of microRNA-21 expression restrains non-small cell lung cancer cell proliferation and migration through upregulation of programmed cell death 4 . Cancer Gene Ther 22: 23-29, 2015.

80. Luo F, Ji J, Liu Y, Xu Y, Zheng G, Jing J, Wang B, Xu W, Shi L, Lu X, et al: MicroRNA-21, up-regulated by arsenite, directs the epithelial-mesenchymal transition and enhances the invasive potential of transformed human bronchial epithelial cells by targeting PDCD4. Toxicol Lett 232: 301-309, 2014. 